\title{
V.I. Romeiko Gurko: Van militêre attaché tot generaal aan die Oosfront
}

Dr C. de Jong*

Van al die militêre attachés wat die Anglo-Boereoorlog aan Britse en Republikeinse kant gedien het, was die Rus V.I. Romeiko Gurko die militêr wat in sy latere lewe die hoogste rang bereik het. In die Eerste Wêreldoorlog was hy tydelik Hoof van die Generale Staf aan die front in Oos-Europa. Sy loopbaan was net so indrukwekkend as dié van sy vader, losef Vladimirovich Romeiko Gurko. ${ }^{1}$ Laasgenoemde is in 1828 gebore te Mohilev, het in 1846 sy graad behaal aan die militêre kollege, "Corps of Pages", en as husaar in die keurkorps die keiserlike garde gedien. Hy het bestuursposte van belang beklee en hom onderskei in die Russies-Turkse oorlog, 1877-78. Hy voer die ruitery aan tydens die langdurige beleg van die stad Plevna in Bulgarye. Hy trek met 70000 soldate in Desember 1877 oor die Balkanberge. Dit was winter en die tog was baie moeilik, vergelykbaar met Napoleon se tog oor die Alpe. Hy het daarna die Turke 'n paar maal verslaan en Adrianopel beset. $\mathrm{Na}$ die oorlog was hy onder meer goewerneur van enkele groot stede. By sy aftrede in 1894 is hy tot veldmaarskalk bevorder. Hy sterf in $1901{ }^{2}$ Voorwaar 'n mooi loopbaan, maar sy tweede seun, Vassilii, sou nie by hom agterstaan nie.

Vassilii (Engels: Basil) losefovich Romeiko Gurko is gebore op $20 \mathrm{Mei}$ (Russiese datum $8 \mathrm{Mei}$ ) 1864 en het in 1885 sy graad behaal aan die militêre kollege ("Corps of Pages") en in 1892 aan die akademie van die Generale Staf sy kwalifikasie behaal. ${ }^{3} \mathrm{Hy}$ was vlot in Engels, Frans en Duits. In 1899 word hy luitenant-kolonel by die kavallerie.

\section{Gurko in Suid-Afrika}

Die Britse Leër het aanvanklik ernstige neerlae gely in die stryd teen die gering geskatte Boere. Die Britse Ryk het as magtigste moondheid van die 19de eeu teenstand van ander moondhede ontlok. Die moondhede was daarom baie geïnteresseerd in die oorlog in Suid-Afrika en van dié lande het militêre attachés na die Britse en die Boereleër gestuur. Die Russiese Generale Staf het ' $n$ attaché, kolonel Pavel A. Stakhovich, na die Britse leër en een attaché, luitenant-kolonel Vassilii I. Romeiko Gurko na die Republieke ge- stuur. Gurko het op die stoomskip 'Natal' op 24 Januarie 1900 in Lourenço Marques aangekom en was op 26 Januarie in Pretoria. Net soos ander attaché's en buitelandse vrywilligers is hy deur die Staatssekretaris, F.W. Reitz, aan president Kruger voorgestel. Hy het geen tyd verlore laat gaan nie en op 1 Februarie in die kamp van kommandant-generaal P.J. Joubert by Ladysmith aangekom. Weens die tydelike stilte aan die Natalse front vertrek hy en ander attachés spoedig na die Vrystaat. Hulle kom op 27 Februarie in Bloemfontein aan. Op dieselfde dag gee generaal P.A. Cronjé hom met sy leër by Paardeberg oor. Dit was die resultaat van ' $n$ verrassende Britse opmars wat die Vrystaat in rep en roer gebring het. Die attachés neem op 7 Maart 1900 die geveg by Poplar Grove waar. Tydens die Boere se vlug het die bagasiewa van Gurko

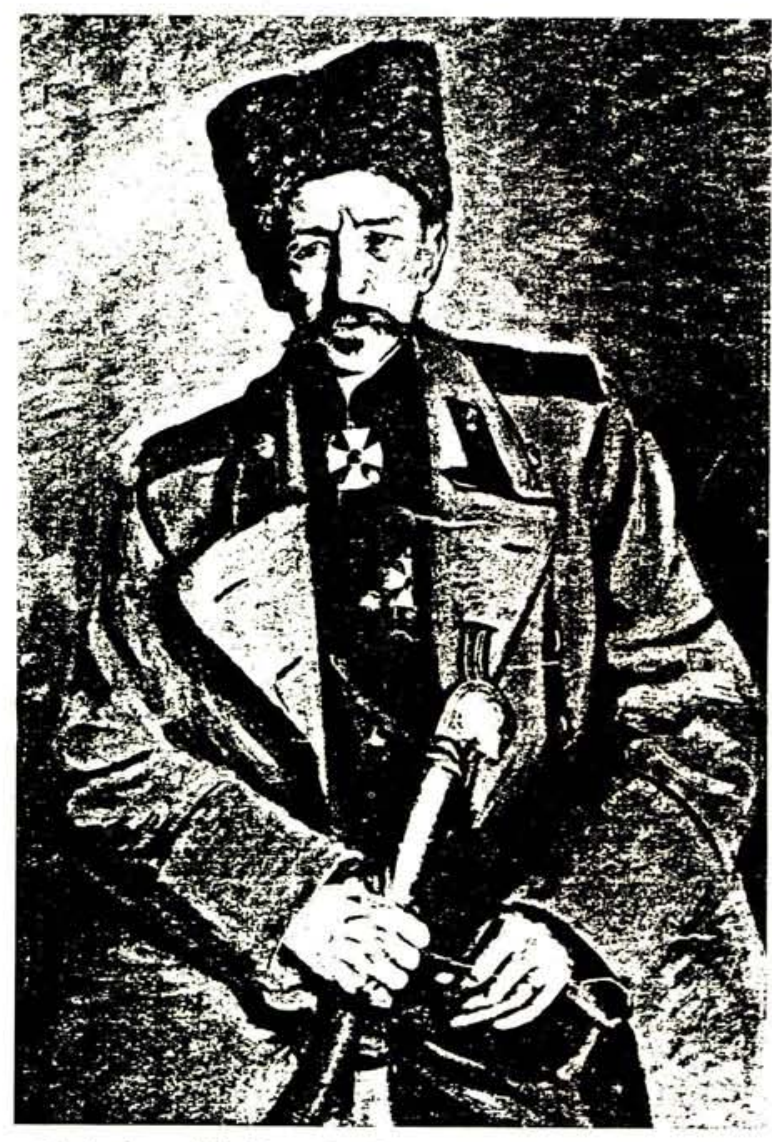

Portret van V.I. Romeiko Gurko as Russiese generaal, geskilder deur Mrs Leslie Cotton in Brittanje in 1917, gepubliseer teenoor die titelblad van sy boek "Memories \& Impressions of War and Revolution in Russia." 
en die Nederlandse attaché, luitenant L.W.J.K. Thomson, gebreek. Hulle twee wou hul bagasie nie prysgee nie en is deur die Britte gevange geneem en na Kaapstad gestuur. Hulle is baie beleefd behandel en aangesê om na Europa terug te keer. Hulle het net so beleefd geweier en toestemming gekry om op die UnionCastle-skip 'Mexican' na Lourenço Marques te vertrek. Via Lourenço Marques het hulle na Pretoria gereis en daar op 29 Maart aangekom. 'n Paar dae later het hulle hul weer by die attachés te Brandfort aangesluit. Hulle het na Kroonstad, tydelike setel van die Vrystaatse regering, gegaan en geloseer in die Grand Hotel, waar hulle by en in die hotel gefotografeer is.

Gurko en die ander attachés het die Boere se terugtog van Brandfort na Kroonstad, Johannesburg en Pretoria meegemaak en saam met die regering van die Zuid-Afrikaansche Republiek, kort voor die ontruiming van Pretoria op 5 Junie 1900, na Machadodorp uitgewyk. Hulle was blykbaar nie by die slag by Donkerhoek op 11 en 12 Junie aanwesig nie, maar het wel die laaste konvensionele veldslag van die oorlog by Belfast, ook Berg-en-Dal en Dal-manutha ge- noem, op 26 Augustus 1900 waargeneem. Daarna het die oorlog (guerrilla) in 'n sluipoorlog verander. Hulle het dié soort oorlog onbelangrik en te veeleisend gevind en saam met president Kruger in September na Lourenço Marques gereis en per skip na Europa teruggekeer. ${ }^{4}$

Ten spyte van sy klein postuur het Gurko opgeval vanweë sy netjiese uiterlik, sy versierde uniform $^{5}$ en sy onverstoorbaarheid onder vyandelike vuur. ${ }^{6}$ Net soos ander attachés het hy na sy terugkeer uit Suid-Afrika 'n uitvoerige, vertroulike verslag oor die oorlog vir sy Generale Staf geskryf. $^{7}$ Die titel (vertaal) lui: "Die oorlog van Engeland teen die Suid-Afrikaanse Republieke" (1901). Sommige van sy briewe uit Suid-Afrika is vertaal en gepubliseer. Verskeie van sy gevolgtrekkings daarin stem ooreen met dié van ander attachés oor die Boere. Hy wys op hul gebrek aan krygstug waardeur hul offisiere min gesag gehad het en die burgers moeilik tot die aanval kon oorgaan, hul afkeer van grootskaalse vernieling van spoorlyne, brûe, rollende materiaal, plaashuise, myne en voorrade, en hul gebrek aan aanvalsgees en strategie, waardeur hulle drie stede nutteloos beleër het. Hy meen dat die

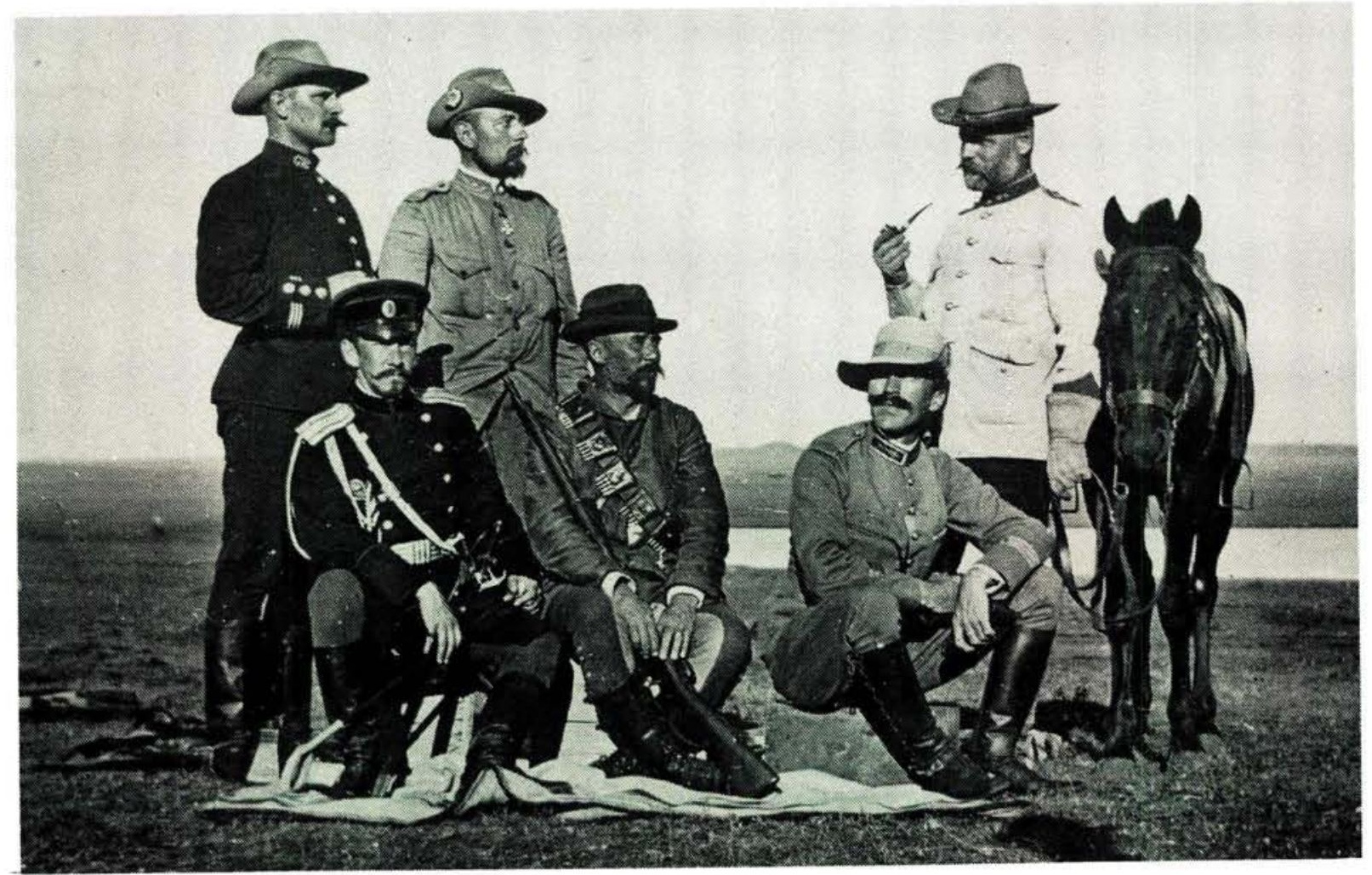

Militêre attachés saam met generaal Tobias Smuts in die veld by Kroonstad in April 1900 gefotografeer. Staande van links na regs: kaptein J. Allum van Noorweë, luitenant L.W.J.K. Thomson (met Militaire Willemsorde op sy bors) van Nederland, en kaptein C. Reichman van die Verenigde State. Sittende: luitenant-kolonel V.I. Romeiko Gurko van Rusland, generaal Tobias Smuts van die Zuid-Afrikaansche Republiek, en kaptein Demange van Frankryk. Foto uit nalatenskap van kaptein J. Allum. 
Boere, ondanks hul vaardigheid in perdry, skiet en die gebruik van die oorlogsterrein vir verkenning en dekking, en ondanks die moontlike lang duur van die sluipoorlog, 'n moderne oorlog moes verloor.

\section{Gurko in Asië}

Gurko het deelgeneem aan die Russies-Japanse Oorlog 1904-05. Volgens een skrywer was hy in die vesting van Port Arthur tydens die verdediging daarvan deur generaal Kondratenko teen die Japanners en het hy uit die vesting weggekom ${ }^{8}$ voordat die generaal gesneuwel het en die vesting oorgegee is. ${ }^{9}$ Hy was offisier aan die front in Mantsjoerye en tydelik hoof van generaal Baron Shtakelberg se staf. In dié hoedanigheid het hy die veldslag by Wafangu meegemaak. Dit het goed begin, maar met Shtakelberg se terugtog geëindig. Gurko is kort daarna van die Russiese linkervleuel na die uiterste regtervleuel verplaas. ${ }^{10}$

Ná die oorlog teen Japan is Gurko, as bekwame verslagskrywer, in Oktober 1906 benoem tot voorsitter van 'n kommissie van hoë offisiere om ' $n$ vertroulike geskiedenis van die Russies-Japanse oorlog te skryf. Hy het die aandag van A.J. Guchkov, veteraan van die Anglo-Boereoorlog en lid van die Theron Verkenningskorps, getrek. Guchkov was 'n vooraanstaande lid van die Doema en voorsitter van die Doema-kommissie vir Verdediging. Die Doema was die parlement wat onder die druk van die revolusionêre poging in Rusland in 1905 ingestel is. Hy het Gurko en nege ander hoë offisiere bereid gevind om die kommissie met leërhervormings te bespreek. Hulle is die "Jong Turke" genoem en het twee jaar lank byeenkomste gehou. Maar die outokratiese regering wou besuinig en van die leërhervorming het voor $1914 \mathrm{~min}$ tereg gekom. ${ }^{11}$

\section{Die Tsareryk by die uitbreek van die Eerste Wêreldoorlog in $1914^{12}$}

Die Russiese Ryk was in 1914 die grootste aaneensluitende staat ter wêreld. Dit was 'n reus wat oppervlakte en aantal mense betref, maar 'n reus op voete van klei. Sy tydgenote, onder wie sy bondgenote, die geallieerdes, het dit nie altyd besef nie. Hulle het in die eerste plek gedink aan die mense-massa wat in die ryk gemobiliseer kon word. Hulle het die ernstige neerlaag van die Tsareryk teen Japan toegeskryf aan gebrek aan organisasie en veral die eindelose lang aanvoerlyne oor die Trans-Siberiese spoorlyn.

Die Tsareryk was in 1914 nog ver agter Westerse lande wat sy ekonomiese, sosiale en staatkundige ontwikkeling betref, en 'n "DerdeWêreld-land", in ons hedendaagse idioom. Rusland was nog oorwegend 'n landbouland. Die nywerheid was nog jonk en van beskeie omvang; die landboumetodes was agterlik en die losmaking van die boer, die eenvoudige moesjik, van onderhorigheid en gemeenskaplike grondeiendom was in volle gang. Ook was die spoorwegnet baie klein in verhouding tot die oppervlakte en aantal inwoners van die land.

Die jong Tsaar Nikolaas II (monarg 1894-1917) was 'n uitgesproke outokraat en demokrasie was nog net 'n droom. Die Tsaar was 'n goedhartige man en goeie gesinshoof, eenvoudig, maar swak van karakter en maklik beïnvloedbaar. Kort na die ongelukkige oorlog teen Japan in 1905 het die ontevredenheid van boere, arbeiders en die middelklas ' $n$ revolusie veroorsaak wat bloedig onderdruk is. Die Tsaar moes egter toegewings maak en 'n soort parlement, die Doema, instel. Die Doema is herhaaldelik deur die Tsaar ontbind en na elke hersamestelling is die invloed van linkse partye beperk. In 1906 het graaf Sergei Witte, die bekwaamste minister en stukrag agter die industrialisering en spoorwegaanleg van Rusland, ontslag geneem. ${ }^{13}$ Daarna het die Tzaar hom merendeels omring van vleiers en intrigante, waaronder daar min bekwame ministers was.

Met die uitbreek van die Eerste Wêreldoorlog op 1 Augustus 1914 was die Tsareryk nie voorberei op 'n moderne oorlog wat jare sou duur, nie. Trouens, ook die ander deelnemers aan die oorlog het nie besef nie dat die oorlog lank sou duur en enorme insette aan soldate, werkers en materiaal - veral wapens en ammunisie - sou vereis. Die kapasiteit van die Russiese wapen- en ammunisiefabrieke en spoorlyne het spoedig geblyk hopeloos ontoereikend te wees vir 'n oorlog wat langer as drie maande duur. Gedurende die hele oorlog het tekorte van velerlei aard die Russiese oorlogspoging ernstig gekortwiek. Die oorlogsindustrie het wèl gepresteer en in die winters, wanneer die koue die oopkap van loopgrawe onmoontlik gemaak en die krygsverrigtinge beperk het, is aansienlike voorrade krygsbenodigdhede opgepot, berig Gurko. ${ }^{14}$ Maar, nadat die offensief in die lente begin het, is die voorrade gou uitgeput. Terwyl die kanonne van die Sentrale Moondhede, Duitsland en Oos- 
tenryk-Hongarye, die Russiese linies met bomme bestook het, moes die Russiese geskut dikwels swyg weens gebrek aan granate.

Die strewe na leërhervorming tussen 1905 en 1914 het slegs beperkte resultate opgelewer weens besuinigings deur die regering. Die 19de eeuse opvattings oor strategie en taktiek, veral onder die ouer offisiere, is slegs min gewysig. By talle van hulle het die uitspraak van maarskalk Suvorov nog gegeld: "The bullet is a fool, the bayonet is a hero." Dit beteken dat die Russiese voetvolk in massa gestorm het om die vyand aan die bajonet te ryg in plaas van hom met kanonen geweervuur te vernietig. Hierdie taktiek het wel ammunisie gespaar, maar het in Wêreldoorlog I tot ontsettende verliese as gevolg van geweer-en masjiengeweervuur gelei.

Die krygstoneel in Oos-Europa het totaal verskil van dié in Wes-Europa, beweer Gurko. Daarom het hy in 1916 'n nuwe militêre handboek saamgestel wat by die omstandighede in Oos-Europa aangepas is. ${ }^{14 a}$ Oos-Europa was ' $n$ gebied van eindelose vlaktes met golwende graanvelde, en hier en daar uitgestrekte moerasse. In die somer was dit warm en stowwerig, in die winter ysig koud met baie sneeu, triestige reëndae met onbegaanbare paaie weens die taai, geel klei, die berugte Poolse modder, waarin alle wiele vasgeval het. Paaie en spoorlyne was skaars. In die winter was die soldate blootgestel aan sneeustorms en ysige koue en baie het doodgevries of hul ledemate verloor as gevolg van die gebrek aan winterklere en gevoerde stewels. Noord van hierdie vlaktes lê die Oossee-kusgebiede met akker- en weilande, afgewissel met uitgestrekte bosse, waarin mense kon verdwaal, en mere en moerasse, soos die Masoeriese mere in OosPruise. Ten suide van die vlaktes strek die Karpategebergte in ' $r$ lang reeks. Die talryke bergpasse in die gebergte is hardnekkig deur die Hongare verdedig. Die Russe het hulle in die Karpate netso vasgeloop as in die bosse en moerasse van Oos-Pruise.

Die klimaat in Oos-Europa is nog meer ongenaakbaar en die lewensomstandighede daar was moeiliker as op die Wes-Europese slagvelde. Die Sentrale moondhede het in Oos-Europa tegnies die botoon gevoer en daarom was die oorlog daar nie voortdurend 'n loopgraaf- of stellingoorlog nie. Dit was weke en maande lank ' $n$ bewegingsoorlog, wanneer een of die ander van die partye honderde kilometers teruggedryf is. $^{15}$
In die oorlogsjare 1914-1916 het die Russe dikwels die Oostenrykers en Hongare teruggedryf, maar teen Duitse offensiewe meestal die onderspit gedelf en teruggewyk. Die verklaring hiervoor is dat die Duitsers ' $n$ baie beter organisasie, transport en logistiekvoorraad as die Russe gehad het en ook die botoon oor die Oostenrykers en Hongare gevoer het.

' $n$ Ander verskil tussen die oorlog in Oos- en Wes-Europa was dat dit in die Ooste meer emosioneel toegegaan het as in die Weste. Byvoorbeeld op Paasdae het die Russe bo hul stellings baniere met die opskrif "Christus is opgestaan" ten toon gestel. Dan was dit die gewoonte om die vyand in sy stellings te besoek, hom die hand te druk, paasbroodjies en eiers as geskenke te oorhandig en afkeer van die vreeslike oorlog te betuig. Soos die oorlog voortgesleep en die Russe steeds oorlogsmoeër geword het, het die verbroedering toegeneem en na die Februarie-revolusie in 1917 algemeen geword, toe die krygstug baie verslap het. ${ }^{16}$ Gurko het as generaal uiteraard sy kommer daaroor uitgespreek. ${ }^{17}$

Die Oosfront, waar Rusland en die Sentrale Moondhede in 'n oorlog gewikkel was, het ver gestrek: van die Oossee in Litoue tot Galisië in Suid-Pole (meer as $1200 \mathrm{~km}$ ). Die toetrede van Roemenië tot die geallieerde magte in Augustus 1916 het die front met $500 \mathrm{~km}$ tot die Swartseekus verleng.

\section{Gurko aan die Oosfront}

Gurko het in die Eerste Wêreldoorlog geluk gehad, of beter uitgedruk, sy Skepper het hom genadig gespaar. Hy is nooit gewond nie en was nie ernstig siek nie. Hy is herhaaldelik van een seksie van die lang Oosfront na 'n ander oorgeplaas en het daardeur die blaam vir die swaar neerlae wat ander generaals gely het, vrygespring. Waar ander generaals uit hul poste onthef is, het hy hom onderskei en het steeds meer leërkorpse onder sy bevel gekry. Hy het tydelik waargeneem as Hoof van die Generale Staf.

By die uitbreek van die oorlog is hy met sy kavalleriedivisie van Moskou na Suwalki in Litoue gestuur. Hy het selfstandig langs die Eerste leërkorps onder Pavel K. Rennenkampf en die Tweede leërkorps onder A. Samsonov geopereer en nie deelgeneem aan hul inval oor die grens van Oos-Pruise nie wat tot ernstige neerlae en verlies van Samsonov se Leërkorps gele 
het. Hy het in Augustus-Oktober drie verkenningstogte oor die grens onderneem. Sy tweede inval was in opdrag van die hoofkwartier en bedoel om verbindings met die Tweede Leërkorps te herstel. Hy het dwarsdeur Duitse linies gevorder tot by Allenstein, besef dat die Tweede Leërkorps verlore was en deur middel van die korps se vinnige marse aan die lot ontkom. ${ }^{18}$

Hy is op 24 November 1914 benoem tot bevelhebber van die Eerste Veldleërkorps in WesPole met, as taak, om die Duitse opmars na Warskou teen te hou. Hy het daarin geslaag en die Bzuralinie in die wintertyd beset te hou. Hy is in April 1915 belas met die bevel oor die 22ste Leërkorps in Galisië, Suid-Pole, en het gehelp om die Oostenrykse-Duitse opmars daar vroegtydig te stuit. Aan die Oosfront, noord van GaliS. het die Duitsers van April tot September 191. tie Russe oral teruggedryf. Die Groot Terugtoy van die Russe het oor honderde kilometers gestrek.

Gurko is in Desember 1915 bevorder tot hoof van die Vyfde Leërkorps aan die rivier Dvina in Letland om daar ' $n$ verdere Duitse opmars via Riga na die Russiese hoofstad Petrograd (voorheen Sint Petersburg) te stuit. Sy teenaanvalle het baie tot die welslae van die veldtog bygedra.

Die Russe het ontsettende verliese aan dooies, gewondes en gevangenes en aan materiaal gely; nog meer as hul teenstanders. Tog het hulle die gevegspouse in die winter 1915/16 gebruik om 'n nuwe offensief voor te berei. 'n Dringende versoek van die Westelike Geallieerdes het die offensiefplan grondig gewysig. Die opmars van Oostenrykers in Noord-Italië het gelei tot die versoek om ' $n$ offensief teen die Oostenrykers in Galisië te begin. Die Russiese opperbevel het ingewillig, soos dit ook vir die Franse versoek in Augustus 1914 ingewillig het om Oos-Pruise voortydig binne te val - wat die Eerste en Tweede Leërkorpse half vernietig het. Gurko kritiseer die Westelike Geallieerdes wat hoër eise aan die Russe as aan hulself stel: "I never could understand how it was that our Allies, having at their disposal means, and more than we .... had one law for their advances and another law for our advances" (p. 146). ${ }^{19}$ Gurko berig dat ' $n$ groot deel van die militêr en materiaal aan die voorgenome offensief in Letland onttrek en na Galisië gestuur is. Daar het generaal A. Brusilov in Mei 1916 deur die Oostenrykse front gebreek en tot eind Augustus hulle ver teruggedryf. Toe was sy reserwes aan soldate en materiaal uitgeput en moes hy die opmars staak. Op sy noordelike vleuel het die keiserlike garde, 'n keurkorps, onder onbekwame leiding sleg gepresteer en tot $70 \%$ verliese gely. Die bevelhebbers is ontslaan, die korps het ' $n$ ander naam, die Spesiale Korps, gekry en Gurko wat aan die Dvina min kon uitrig, is in Augustus 1916 met die aanvoer belas. ${ }^{20}$ Hy moes Brusilov se doodgeloopte offensief in Galisië hervat en het op 16 en 17 Oktober 1916 'n groot aanval geloods. Maar die Duitsers het die benarde Oostenrykers te hulp gesnel en Gurko se aanval is afgeslaan. ${ }^{21}$ Toe het daar voorlopig ' $n$ einde gekom aan omvangryke krygsoperasies aan die Oosfront. Roemenië het in Augustus 1916 te laat tot die Geallieerde kamp toegetree. Die Roemeense leër is spoedig teruggedryf, die Russe moes die Oosfront deur Roemenië tot die Swartseekus verleng en die front in Roemenië is gestabiliseer langs die Karpategebergte en die rivier Sereth. Die strydende partye het hul kragte bewaar vir die offensief in 1917.

In November 1915 is groothertog Nikolaas as opperbevelhebber aan die Oosfront weens die teenslag van die Groot Terugtog vervang deur Tsaar Nikolaas wat eweneens sy hoofkwartier te

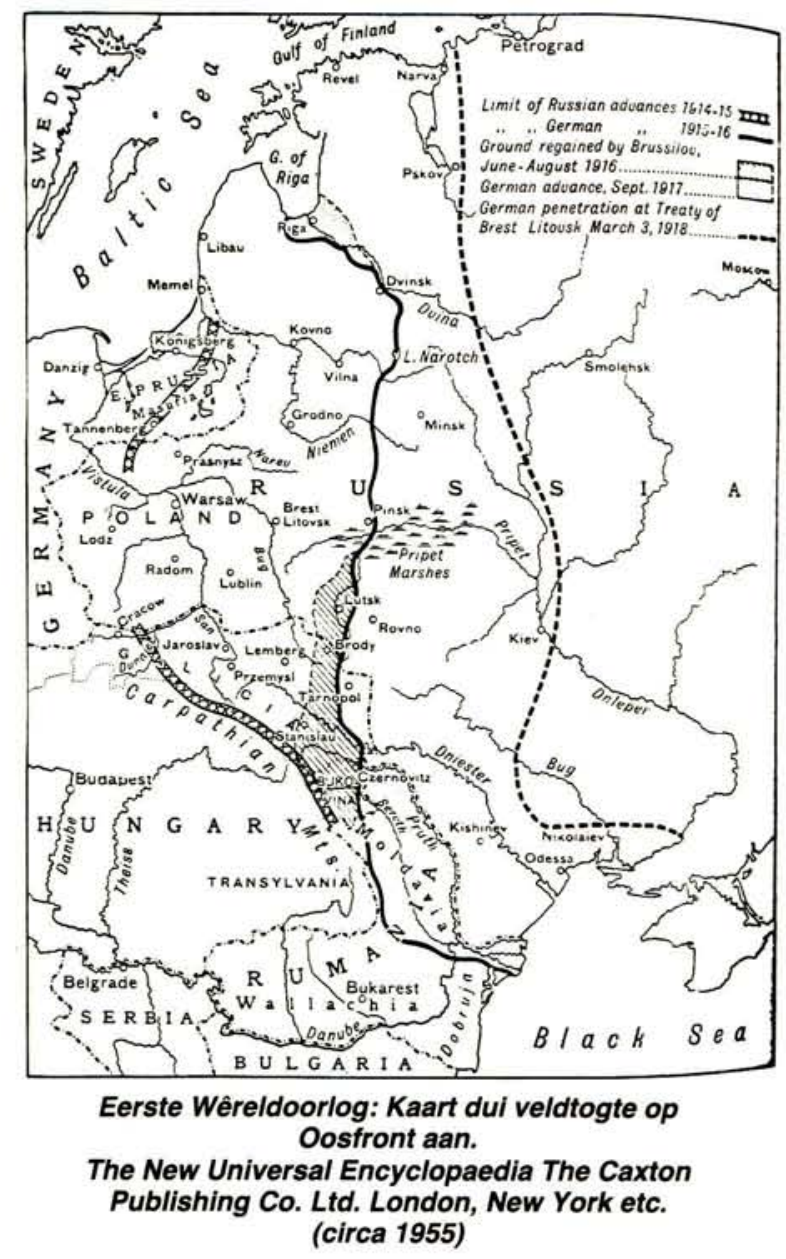


Mohilev gevestig het. Generaal M.V. Alexeiev het hoof van die Generale Staf gebly. Hy moes in November 1916 met siekteverlof gaan. Hy was Gurko goedgesind en op sy advies het die Tsaar Gurko as waarnemende hoof van sy staf aangestel. Gurko het van 23 November 1916 tot Maart 1917 waargeneem. Hy het toe ' $n$ leërhervorming ingevoer deur die te groot leërdivisies te verminder van 16 na 12 bataljons. Hy was in Januarie 1917 voorsitter van die Intergeallieerde konferensie te Petrograd waar hy onder andere Alfred Milner as verteenwoordiger van Brittanje ontmoet het. Daar is besluit om in 1917 die Sentrale Moondhede op alle fronte gelyktydig aan te val. In Maart 1917 het Alexeiev sy werk as stafhoof te Mohilev hervat. Hy sou die groot offensief aan die Oosfront voorberei. Gurko is benoem tot bevelhebber oor die middelste seksie van die front met sy kwartier by Minsk.

\section{Die Revolusie}

Maar intussen het daar op 15 Maart 1917 (Russiese datering Februarie) in Petrograd 'n revolusie uitgebreek wat vinnig na stede en die platteland uitgebrei het. Na die mislukte omwenteling in 1905 het die sosiale onrus voortgeduur en boere en arbeiders was ontevrede. In die somer van 1914 was daar weer groot stakings in sommige stede. Toe die Eerste Wêreldoorlog uitbreek, het die outokratiese regering, die Doema, en werkgewers en werknemers 'n soort godsvrede gesluit om sterk teen die buitelandse vyand te staan. Maar in die volgende drie oorlogsjare het die regering ontoegeeflik gebly, die aantal dooies, gewondes, verminktes en krygsgevangenes het een miljoen oorskry. Die arbeiders in die wapenindustrie en die spoorweë moes steeds meer presteer sonder verhoging van hul reële beloning en in die stede het voedseltekorte en prysstygings ingetree, nie omdat daar misoeste was nie, maar omdat die vervoer oor die oorbelaste spoorweë gestagneer het.

Die oorgroot meerderheid van die leër het bestaan uit kleinboere (moesjieks) wat van ouds mineisend en gedwee was en as kanonvoer gewillig met die bajonet gestorm het. Gurko wys egter op die oorgang van gemeenskaplike na individuele grondeiendom wat sedert enkele jare aan die gang was, en skryf op p. viii: "This farreaching reform, though hardly apparent to the stranger, profoundedly (sic) affected the interests of the great Russian peasant population, which forms more than 90 per cent of the Army's recruits."22 Dit impliseer dat die gedagtes van die soldate by hul plase en nie by die oorlog was nie en dat hulle begerig was om huis toe te gaan en nie om die oorlog te wen nie.

Toe die Doema volgehou het met kritiek en vra om demokratiese hervorming, het Tsaar Nikolaas dit verdaag. Maar die Doema het geweier om uiteen te gaan, ' $n$ komitee na die Tsaar gestuur en hom met die oog op die algemene sosiale onrus gevra om afstand te doen van sy troon. Nikolaas het dit met opvallende gewilligheid gedoen en ' $n$ Voorlopige Regering is saamgestel. Daarnaas het die kommuniste oral rade van arbeiders en soldate ingestel en begin met die ondermyning van die arbeidstug en militêre tug. Die Voorlopige Regering wou die oorlog kragtig voortsit en Guchkov is as minister van oorlog aangewys. Hy was 'n kennis van Gurko, wat oor hom skryf (p. 282): "It is true that during his life he had smelt powder, for he had been a volunteer in the Boer War where he was seriously wounded."23

In Mei 1917 het die regering onder druk van die kommuniste 'n nuwe reglement vir die regte van soldate uitgevaardig. Dit sou die militêre tug verder aantas. Guchkov het daarom afgetree en sommige hoë offisiere, onder wie Alexeiev en Gurko, het ernstige beswaar by die regering aangeteken. Guchkov is as minister van oorlog opgevolg deur die radikale $A$. Kerensky wat in Augustus 'n soort diktator geword het. Hy het die reglement bekragtig en op 5 Junie Alexeiev, Gurko en 'n paar ander offisiere ontslaan. Bussilov het Alexeiev as hoof van die Generale Staf opgevolg.

Die beplande offensief is op 1 Julie 1917 in Galisië begin, maar het spoedig doodgeloop en bloedig misluk omdat die beskikbare wapens en ammunisie weens lae produksie tydens die onrus gering was, en omdat die soldate oorlogsmoeg was, soos die grootste deel van die Russe. In September 1917 het die Duitsers opgeruk en Letland, Estland, Wit-Rusland en die Oekraïne beset. Die kommuniste het op 7 November (Russiese datering 25 Oktober) 1917 ' $n$ tweede revolusie ontketen en die mag van die swak Voorlopige Regering oorgeneem. Hulle wou die oorlog tot elke prys beëindig en het in Desember 1917 met die Sentrale Moondhede ' $n$ wapenstilstand en in Maart 1918 die uiters nadelige vrede van Brest-Litovsk gesluit.

Gurko het op 5 Junie 1917 'n amptelose burger geword. Sy eggenote was gedurende die hele 
oorlog verpleegster aan die Oosfront en hulle het mekaar selde gesien. Sy was, soos hy, lid van die Russiese aristokrasie. Toe die Balkanoorlog in 1912 uitbreek, het hulle in Moskou gewoon. Volgens Gurko het sy toe gesê dat dit die voorspel van 'n groot Europese oorlog was en ' $n$ verpleegsteropleiding van 8 maande gevolg. Verpleging was 'n vak wat vir dames van die Russiese aristokrasie aanbeveel is. Die Tsarina en haar dogters het die voorbeeld gestel en ' $n$ verpleegsterskursus gevolg. Mevrou Gurko het in die lente van 1912 die eerste eksamen in haar lewe afgelê, gekwalifiseer as genadesuster (Sister of Charity) en in Augustus 1914 Von Rennenkampf se Eerste Leërkorps in Oos-Pruise gevolg. Sy het daarna in tien verbindingshospitale onmiddellik agter die Oosfront gewerk en steeds as voorwaarde gestel dat sy die enigste verpleegster onder die manlike mediese personeel sou wees. By die min ontmoetings met haar eggenoot het sy hom oor mediese vraagstukke ingelig, sodat hy gewenste maatreëls kon neem. Sy was van mening dat selfs in primitiewe toestande streng eise vir mediese behandeling nagekom kon word.

Hulle het saam na Petrograd gereis om hul sake te reël en te emigreer. Die Voorlopige Regering het hom op 4 Augustus 1917 laat arresteer en hy is in die Petrus- en Poulus-vesting gevangenis gesit - vier weke lank. ${ }^{24}$ Omdat daar geen aanklagte teen hulle gelê is nie, is hulle toe vrygelaat en uit Rusland verban. Hulle het op 15 Oktober 1917 in Moermansk aan boord van die Britse passasierskip 'Umthali' gegaan. ${ }^{25}$ Drie weke later het hulle in Brittanje aangekom.

Hulle is daar vriendelik ontvang, onder andere deur koning George V, tot ergernis van die Voorlopige Regering. ${ }^{26}$ Mrs Leslie Cotton het Gurko se portret in generaalsuniform met kommandostaf geskilder. ${ }^{27}$ Hulle het spoedig na Parys vertrek. Gurko het daar sy herinneringe aan die Eerste Wêreldoorlog en die revolusie in Maart beskryf en in Maart 1918 voltooi. Dit is 'n boeiende werk in goeie styl geskryf, want Gurko was ' $n$ intellektueel met skrywerstalent. Van belang is sy tipering, hoewel versigtig, van talle persone.

Hy en sy gade het aan die gevare van die oorlog en die woelinge van die Februarie- en Oktoberrevolusies in Rusland ontkom, maar daarna het die oorlog wat in Wes-Europa nog in volle gang was en sy klimaks in 1918 sou bereik, hulle swaar getref. Mev. Gurko het op 15 Desember 1917 aangemeld vir werk in 'n verbindingshospi- taal aan die Wesfront. Daar is sy op 23 Maart 1918 deur 'n Duitse granaat gedood. Diep bedroef het Gurko sy pas voltooide boek aan haar opgedra. ${ }^{28}$ Dit het nog in 1918 by John Murray in Londen verskyn en is in 1921 deur Hutchinson in Londen heruitgegee. In dieselfde jaar het ' $n$ vertaling in Duits in Berlyn verskyn. ${ }^{29}$ By die verskyning van die boek in 1918 was die oorlog nog aan die gang en Gurko moes sy aandeel aan die Geallieerde oorlogspropaganda lewer. Daarom skryf hy in sy woord vooraf (p.v.): "During the last few years, all the wars of civilised nations were prepared ... by German diplomacy, guided by the War Lord, William. It is enough here to recall his telegram to the President of the Transvaal Republic, Kruger, at the moment when this small State had to decide for war or peace with England." Hy weerlê in die woord vooraf die optimistiese verwagting onder die Geallieerdes dat die Februarie-revolusie in 1917 die Russiese oorlogspoging sou vergroot, soos die Franse Revolusie in 1792-99 gedoen het. Hy betoog dat die oorlogsoorwinnings van die Franse Republiek in 1792-99 die gevolg van die revolusie in 1789 was en dat in Rusland die posisie die omgekeerde was: daar is die revolusies van 1905 en 1917 die gevolg van 'n oorlog wat ongunstig verloop het.

Gurko het hom na die Vrede van Versailles in Parys gevestig, net soos talle ander Wit Russe: teenstanders van die rooi, kommunistiese Sovjetbewind, en voortvlugtige lede van die Voorlopige Regering, soos Guchkov en Kerensky. Hy het die aanbod om in 1919 'n leër van Wit Russe teen die Sovjetregering in Noordwes-Rusland aan te voer, afgewys. ${ }^{30} \mathrm{Hy}$ is op 11 November 1937 in Rome oorlede.

Hy is ' $n$ begaafde en dapper militêre aanvoerder en ' $n$ talentvolle organiseerder en skrywer genoem. Een historikus berig oor Alexeiev as hoof van die Generale Staf: "He had a competent successor as Chief of Staff of the Army in Gurko, whose energy and ability had brought him rapidly to the top". ${ }^{31}$ W. Bruce Lincoln (p. 309) skryf oor hom: "A small, dapper general who had fought in Central Asia's Pamir and as Russia's military attaché had been captured by the British during the Boer War, Gurko at the age of 50 had led a division of Rennenkampf's cavalry into East Prussia. Since then he had risen to command a corps and then an army before he had been appointed as Alexeiev's temporary replacement". ${ }^{32}$

Bogenoemde persone in Gurko se kring het 'n 
uiteenlopende lot ervaar. ${ }^{33}$ Tsaar Nikolaas en sy gesin is deur kommuniste in Julie 1918 te Jekaterinaburg in Siberië doodgeskiet. Stakhovich het generaal geword en is, soos berig, deur die kommuniste tereggestel. ${ }^{34}$ Alexeiev het in die stryd teen die Rooi Leër gesneuwel. Brussilov, wat deur Gurko 'n opportunis genoem is, het 'n generaal in die Rooi Leër geword. Guchkov en Kerensky het na afloop van die Oktober-revolusie na Parys uitgewyk.

${ }^{\star}$ Dr C de Jong. professor in Ekonomiese Geskiedenis, Universiteit van Suid-Afrika vanaf 1965 tot 1986.

\section{Verwysings}

1. Russiese name word in ander tale op talle, uiteenlopende wyse gespel. Ek volg eenvoudigheidshalwe die spelling in Engelse werke, met name in deur my gebruikte boeke van Ward Rutherford, "The Russian Army in World War I", Londen 1975, en W. Bruce Lincoln, "Passage through Armageddon, The Russians in War and Revolution, 1914-1918", New York 1986.

2. Artikel Gurko, losef Vladimirovixh, in "Great Soviet Encyclopaedia, A translation from the third edition", MacMillan, New York 1970, volume 7. p. 409 .

3. Artikel Gurko, Vesilli losefovich (V.I. Romeiko Gurko), in "Great Soviet Encyclopaedia", volume 7, p. 409.

4. Oor V.I. Romeiko Gurko kyk:

E. Foxcroft and $C$. de Jong, "Reports of neutral military observers during the Anglo-Boer War 1899-1902. The reports of the Russian military attachés 1899-1900", in "Militaria, Military-historical periodical, South African Defence Force", volume 5 nr. 3, p. 1-21, nr. 4, p. 49-59, Pretoria 1975.

M.C. van Schoor red. "Depêches van die Russiese attachés, kol Stakhvich en It kol Gurko, vertaal uit die Russies deur E. WillaimsFoxcroft", in "Christiaan de Wet Annale no. 3," uitgegee deur die SuidAfrikaanse Akademie vir Wetenskap en Kuns, Pretoria, Oktober 1975. p. $123-202$.

Elizavetha Kandyba-Foxcroft, "Russia and the Anglo-Boer War 1899-1902", Christelike Uitgewersmaatskappy, Roodepoort 1981, hierin p. $152-154$, p. $162-175$.

5. C.G.S. Sandberg. "Twintig jaren onder Krugers Boeren in voor- en tegenspoed", Amsterdam 1943, p. 309, noot, skryt: "Luitenant-kolonel Gurko, klein en tenger, altoos (altyd) even keurig en correct gekleed, heeft het op mysterieuze wijze en tot onze stomme verbazing en bewondering zelfs klaar kunnen spelen zijn lange, licht-blauw-grijze overjas, waarin hij zich 's nachts als eenige dekking wikkelde, smetteloos rein te houden, evenals zijn uniform, hoewel hij, evenals wij, de laatste dagen in het veld op den kalen grond had moeten slapen!"

6. R.W. Schickerling, "Commando courageous, A Boer's diary", Hugh Keartland Publishers, Johannesburg 1964 (ook in Afrikaans verskyn onder die titel "Hoe ry die Boere"), p. 49 oor Gurko se bywoning van die slag by Dalmantha: "A Russian attaché on a gaily caparisoned horse rode up from some adjoining position and hailed us in German .... when a shrapnel exploded over our heads... The Russian's horse was struck on the nose... the animal plunged, but the rider remained quite calm, asking us in an ignorant sort of way whether his horse was "kaput' (finished).

7. V.I. Romeiko Gurko, "Voina Anglii S. Ushno-Afrikanskni republikani" (titel in Engels: England's war with the South African republics, Confidential report of Col(onel) Romeiko-Gurko of the General Staff written upon orders of His Imperial Majesty) 1901 in bibliography of $E$ Kandyba-Foxcroft, "Russia and the Anglo-Boer War", p. 384.

8. Sandberg T.A.P. verwysing 6, skryf in 1943 oor Gurko: "later beroemd door zijn ontsnapping uit het door de Japanners belegerde Port Arthur".

9. Gurko skryf in sy "Memories \& Impressions of War and Revolution in Russia 1914-1917" (Londen 1918) op p. 79, oor "the Spirit of the defence of the fortress", dit is hier die vesting Port Arthur; hy bedoel die moreel onder die beleerdes, hooggehou deur die bevelvoerder. Hy vervolg: "Such a personality was defender of the Port Arthur fortress General Kondratenko, who was killed in the siege. With his death fell the spirit of the defenders and soon it fell into the hands of the Japanese."
10. Gurko ta.p. verwysing 9; hy vermeld verskeie hoë Russiese offisiere met Duitse familiename, soos Pavel (von) Rennenkampf, Evert, Shtakelberg. Schwartz, Sheideman en Von Mannerheim, Russiese generaal aan die Oosfront, na die Revolusie in 1917 aanvoerder van die Finne teen die kommuniste en eerste staatspresident van Finland. Hul voorouers was Duitsers wat hulle gevestig het in die Baltiese of Oosseestate in Swede of Finland en vandaar in militêre diens in Rusland gegaan het; die medikus K.K. von Rennenkampt het as lid van die Russies-Nederlandse ambulans in Januarie 1900 na Suid-Afrika gekom en was na die vertrek van die meeste buitelandse ambulanse uit Suid-Afrika in 1900 een van die drie Bittereinders wat as buitelandse medici die Boerekommando's tot die einde van die oorlog bygestaan het; E. Kandyba-Foxcroft t.a.p. verwysing 4, p. 206-212.

11. W. Rutherford, "The Russian Army in World War I", p. 21; Gurko t.a.p. p. 280 insake sy kontak met Guchkov en die "Jong Turke".

12. Die stof vir die agtergrond van die Tsareryk in die Eerste Wêreldoorlog is deur die skrywer veral ontleen aan die twee volgende werke uit die baie omvangryke literatuur gekies:

Ward Rutherford, "The Russian Army in World War I", uitgewer Gordon Cremonesi, Londen 1975, 303 pp. 'n bondige werk.

W. Bruce Lincoln, "Passage through Armageddon, The Russians in War and Revolution, 1914-1918", uitgewers Simon \& Schuster, New York 1986, 637 'n uitvoerige werk.

13. Rutherford t.a.p. verwysing 11, deel mee op p. 93 dat Witte in Augustus 1914 kort na die uitbreek van die oorlog die Franse gesant in Petrograd, Paléologue, besoek het; hy het hom nadruklik teen die oorlog verklaar omdat syns insiens Rusland nie in staat was om 'n moderne oorlog te voer nie; hy was tot so 'n oordeel bevoeg. "He ended: My practical conclusion is that we must liquidate this stupid adventure as soon as possible." Hy het in 1915 gesterf en dus nie beleef dat sy voorgevoel juis was nie.

14. Gurko ta.p. verwysing 9, p. 131 e.v., hoofstuk "The critical winter of 1915/1916"; hierin het Rusland weer kragte vir 'n hernude en suksesryke offensief in 1916 versamel wat die einde van die oorlog met 'n jaar vertraag het. Hy betoog tereg dat niemand die materiële poging van Rusland in die oorlog mag onderskat nie; die wapenindustrie is aansienlik uitgebrei en die spoorweë, wat permanent oorbelas was, het groot prestasies gelewer: die Trans-Siberiese spoorweg is oor groot afstande verdubbel en 'n spoorweg van Petrograd na Moermansk is aangelê en in Desember 1916 geopen, egter te laat om die verloop van die stryd te beïnvloed. Kyk Gurko t.a.p. p. 22, 216. Maar al die inspanning was ontoereikend

14a. Gurko t.a.p. verwysing 9, p. 141.

15. Waar geen bron oor die 0orlog in Oos-Europa in die teks van hierdie seksie vermeld is nie, is die stof vir die teks hoofsaaklik ontleen aan Rutherford en Bruce Lincoln, t.a.p. verwysing 12 bo.

16. Rutherford t.a.p. verwysing, p. 119

17. Gurko t.a.p. verwysing 9, p. 293.

18. Gurko ta.p. verwysing 9 hoofstuk 6 ; waar Rutherford en Bruce Lincoln nie aangehaal word nie, is die boek van Gurko my bron.

19. Gurko t.a.p. verwysing 9 p. 146.

20. Rutherford t.a.p. verwysing 12, p. 215 , Gurko t.a.p. verwysing 9 p. 157

21. Rutherford t.a.p. verwysing 12, p. 221-222; Gurko verwysing 9, p. 162.

22. Gurko t.a.p. verwysing 9 , p. viii.

23. Gurko verwysing 9, p. 282

24. Gurko t.a.p. verwysing 9, p. 169; die "Great Soviet Encyclopaedia" t.a.p. verwysing 3 , volume 7 , gee as redes vir Gurko se ontslag en sy aanhouding deur die Voorlopige Regering politieke onbetroubaarheid en "pro-monarchist statements", wat juis kan wees, asook sy "correspondence with the Tsar", hierdie briefwisseling bestaan waarskynlik uit die brief wat Gurko op 4 Maart 1917 (Russiese datering) aan die Tsaar, enkele dae na dié se troonafstand, gestuur het en waarin hy sy simpatie met Nikolaas II uit; Gurko het die teks van sy brief opgeneem in sy boek "Memories \& Impressions", p. 331-333.

25. Gurko eindig sy boek met vermelding van aankoms van hom en sy eggenote in Brittanje in November 1917.

26. Rex A. Wade, "The Russian search for peace, February-October 1917", Stanford University Press, California 1969, p. 125.

27. Afbeelding van die portret teenoor titelblad van Gurko se boek "Memories \& Impressions",

28. Gurko t.a.p. verwysing 9 , opdrag "To my wife", p.v.; hy noem nêrens die naam van sy eggenote nie.

29. Die volgende uitgawes van Gurko se boek het verskyn: Generaal Basil Gurko, "Memories \& Impressions of War and Revolution in Russia, 1914-1917"; uitgegee deur John Murray, Londen 1918; en heruitgegee deur Hutchinson, Londen 1921.

Vassilii Gurko, "Russland 1914-1917, Erinnerungen an Krieg und Revolution", Deutsche Verlagsgesellschaft für Politik und Wisselschaft, Berlyn 1921. 
30. "Great Soviet Encyclopaedia" t.a.p. verwysing 3, in voce Gurko, dit Vassilii I Romeiko Gurko.

31. Bernard Pares, "The fall of the Russian Monarchy A study of evidence", New York 1961.

32. Bruce Lincoln ta.p. verwysing 12, p. 309.

33. Rutherford ta.p. verwysing 12, p. 259.

34. Dit is jammer dat baie min oor die lewe en loopbaan van Stakhovich, Russiese militêre attaché by die Britte in Suid-Atrika in 1900, bekend is. Versoeke om inligting oor hom, deur mev. E. Kandyba-Foxcroft en dr. E.A. Schmidl aan instansies in die USSR gerig, is nie beantwoord nie. Schmidl vermeld in die boek van Jay Stone and Erwin A. Schmidl, "The Boer War and military reforms", New York 1988, Stakhovich onder die militêre attachees in die Anglo-Boere-oorlog 1899-1902, p. 322 en eindig: Stakhovich was promoted Lieutenant General in 1913 and commanded an army in the Great War. He was imprisoned during the revolution in 1917 and was later allegedly murdered by the Communists". 
